\title{
Effect of indomethacin on binding of bilirubin to albumin
}

\author{
B C C Lam, H N Wong, C Y Yeung
}

\begin{abstract}
The effect of indomethacin on the binding of bilirubin to protein was studied in vitro by the horseradish peroxidase oxidation method. Plasma indomethacin concentrations ranging from $1500 \mu \mathrm{g} / 1$ to $4500 \mu \mathrm{g} / 1$, which were much higher than the therapeutic concentrations achieved in vivo, were used for the studies. The bilirubin-protein titration curves obtained indicate that indomethacin, although protein bound, does not affect the binding of bilirubin to protein. Our study confirms that it is safe to use conventional doses of indomethacin in jaundiced preterm infants.
\end{abstract}

Patent ductus arteriosus is common among premature infants, and indomethacin, a prostaglandin inhibitor, is widely used to induce closure. One of the alleged contraindications for its use in preterm neonates is hyperbilirubinaemia. ${ }^{2}$ As the drug is mainly bound to albumin it may have the potential to displace bilirubin from its albumin binding. ${ }^{3}$ The ability of indomethacin to induce closure of the ductus is considerably reduced when it is used after 10 to 14 days postnatal age, ${ }^{4}$ but as hyperbilirubinaemia is a common problem among Chinese preterm infants during the first two weeks of life, we had been postponing the use of indomethacin until the hyperbilirubinaemia had subsided. We therefore had a high rate of failure to close the ductus in our preterm infants.

We report here the effects of indomethacin on the binding of bilirubin to albumin assessed in vitro by the horseradish peroxidase oxidation method.

\section{Material and methods}

The intravenous preparation of indomethacin (Merke Sharp and Dohme) was evaluated. Bilirubin-protein titration studies were carried out by the horseradish peroxidase oxidation method described by Jacobson and Wennberg. ${ }^{6}$ Horseradish (Sigma) and pooled cord blood serum were used. Lyophilised indomethacin powder was added to $2 \mathrm{ml}$ aliquots of serum to make up concentrations of $1500 \mu \mathrm{g} / \mathrm{l}, 3000 \mu \mathrm{g} / \mathrm{l}$, and $4500 \mu \mathrm{g} / \mathrm{l}$, which are multiples of the highest therapeutic concentration described according to the current recommended dose of $0.1 \mathrm{mg} /$ $\mathrm{kg}-0.4 \mathrm{mg} / \mathrm{kg}^{7-9}$ The mixture containing indomethacin and phosphate buffer at $\mathrm{pH} 7 \cdot 4$ was incubated at $37^{\circ} \mathrm{C}$ for one hour. The incubated serum was then used to titrate with bilirubin by an automated peroxidase oxidation method. ${ }^{10}$

The peroxidase oxidation method is a sensitive enzymatic method using horseradish peroxidase for measuring low concentrations of free bilirubin. Free bilirubin is oxidised by hydrogen peroxide in the presence of peroxidase enzyme. Excess albumin inhibits the oxidation process by binding the free bilirubin. As the bilirubin and albumin equilibrate more rapidly compared with the rate at which unbound bilirubin is oxidised, the oxidation step limits the rate. The concentration of free bilirubin can therefore be determined from the initial rate of bilirubin oxidation measured by direct spectrophotometry of the incubated mixture after a timed exposure to peroxidase and hydrogen peroxide. The bilirubin to protein titration curve was then compared with a normal serum control containing no indomethacin. Phosphate buffers without serum but containing the same tested doses of indomethacin were also studied to examine the possible influence of indomethacin on the activity of the peroxidase oxidation enzyme.

\section{Results}

The amounts of free bilirubin generated from various bilirubin-albumin molar ratios in the

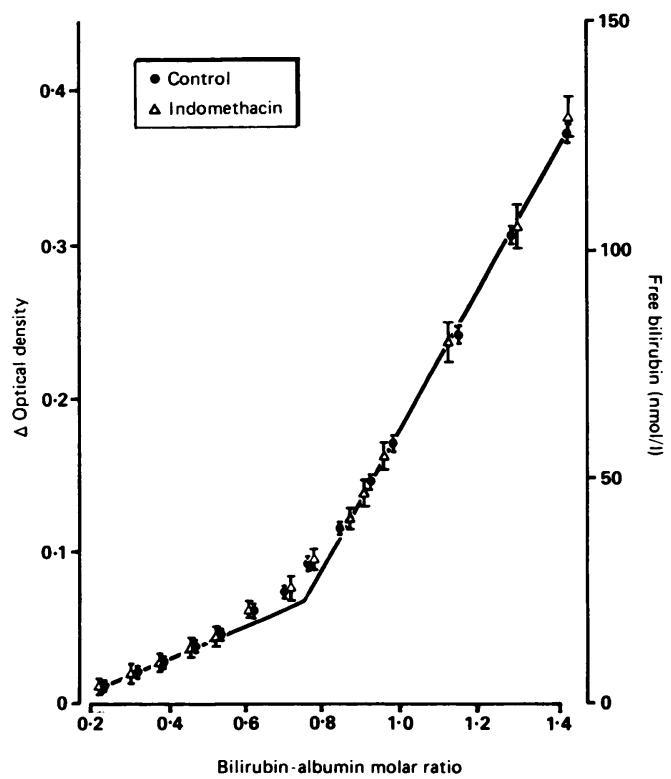

Figure 1 Titration studies gave identical results with or without indomethacin even at the highest concentration of $4500 \mu \mathrm{g} / \mathrm{l}$. Titration curves at $1500 \mathrm{\mu g} / \mathrm{l}$ and $3000 \mathrm{\mu g} / \mathrm{l}$ also showed identical findings (not plotted). 


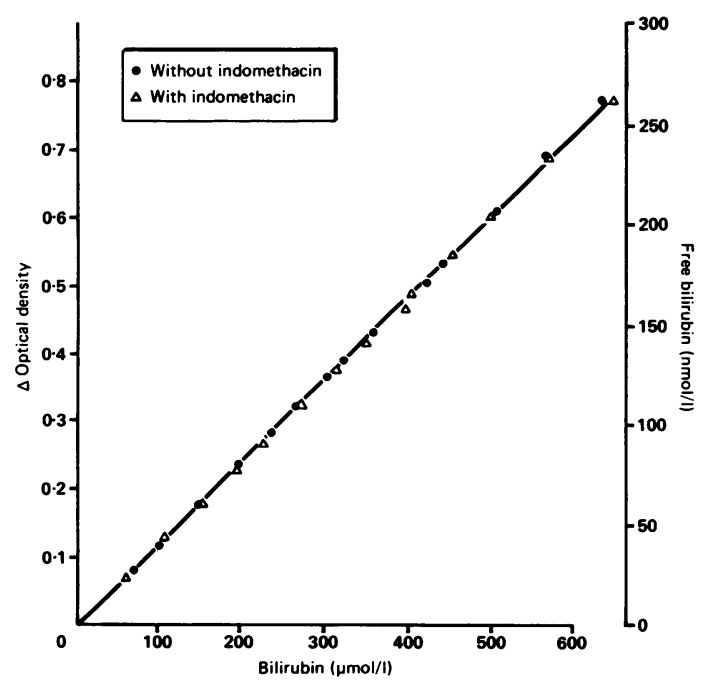

Figure 2 Linear relationship between total bilirubin in phosphate buffer solution and free bilirubin as determined by the horseradish peroxidase oxidation method. This relation is not affected by addition of high concentrations of indomethacin up to $4500 \mu \mathrm{g} / \mathrm{l}$. Lower concentrations ( 1500 $\mu \mathrm{g} / \mathrm{l}$ and $3000 \mu \mathrm{g} / \mathrm{l})$ show identical results.

presence of $1500 \mu \mathrm{g} / \mathrm{l}, 3000 \mu \mathrm{g} / \mathrm{l}, 4500 \mu \mathrm{g} / \mathrm{l}$ of indomethacin were the same as that obtained from normal serum control, as shown by the bilirubin to protein titration curves (fig 1). This indicates that indomethacin, although protein bound, does not affect bilirubin-protein binding even at concentrations far higher than the therapeutic range.

There was a linear relationship (fig 2) between the amounts of total bilirubin and free bilirubin in the phosphate buffer control with and without indomethacin, indicating that indomethacin does not enhance or inhibit the peroxidase oxidation reaction.

\section{Discussion}

Indomethacin is widely used to close the patent ductus arteriosus in the neonates, but because of its protein binding properties, many workers have suggested that it should not be used in the presence of hyperbilirubinaemia. This often leads to unnecessary delay in it being given, and hence higher failure rates (as we have found among our preterm infants). Pharmacokinetic data on preterm neonates have shown that after an oral dose of $0.2 \mathrm{mg} / \mathrm{kg}$, blood concentrations of $27-1500 \mu \mathrm{g} / \mathrm{l}$ are achieved, with the peak at $0.5-6$ hours. ${ }^{11} 12$ After $0.2-0.3 \mathrm{mg} / \mathrm{kg}$ has been given intravenously, blood concentrations are between 1000 and $2500 \mu \mathrm{g} / \mathrm{l}$. The half life is prolonged to as long as $\mathbf{4 0}$ hours in the very low birthweight infants because of immature renal and hepatic function, and also perhaps because of the enterohepatic circulation.

Mason and McQueen have found that human serum albumin possesses two classes of binding sites for indomethacin. ${ }^{13}$ Albumin also has two binding sites for bilirubin, only one of which has a high affinity that is shared by acidic drugs. ${ }^{14}$ It is therefore possible that bilirubin and indomethacin do not share common binding sites to albumin under usual therapeutic conditions. Some studies have shown that indomethacin in high doses may displace bilirubin. ${ }^{12}$ This may indicate that indomethacin competes with bilirubin for additional binding sites when its own are saturated.

The effect of indomethacin on bilirubin albumin binding has been studied by Shankaran $e t$ al using the hydroxybenzene azobenzoic acid dye binding method. ${ }^{15}$ They used a drug concentration of $2000 \mu \mathrm{g} / \mathrm{l}$ and did not find any displacement of bilirubin. Recently some workers have advocated prolonging the course of indomethacin by up to a week or even 10 days to avoid reopening of the ductus. ${ }^{16}$ Such cumulative doses of indomethacin may result in much higher blood concentrations. Furthermore, there are important individual fluctuations in indomethacin deposition making adjustment of the dose difficult even with careful monitoring. We have found no displacement of bilirubin by indomethacin even at the high concentration of $4500 \mu \mathrm{g} / \mathrm{l}$. This study was, however, done in vitro at physiological $\mathrm{pH}$, and one must be aware that conditions may be different in ill preterm infants who are often hypoxic, with acidaemia and electrolyte disturbances.

In summary, we found no displacement of bilirubin from albumin by indomethacin with usual therapeutic doses thus confirming that it is safe to use conventional doses of indomethacin in jaundiced preterm infants.

1 Bianchetti G, Monin P, Marchal F, et al. Pharmacokinetics of indomethacin in the preterm infant. Dev Pharmacol Ther 1984;1:111-24.

2 Yeh TF, Luken JA, Thalji A, Raval D, Carr I, Pildes RS. Intravenous indomethacin therapy in premature infants with persistent ductus arteriosus - a double-blind controlled study. $\mathcal{f}$ Pediatr 1981;98:137-45.

3 Bhat R, Vidyasagar D, Vadapalli $M$, et al. Disposition of indomethacin in preterm infants. F Pediatr 1979;95:313-6.

4 Obeyesekere HI, Pankhurst S, Yu VYH. Pharmacological closure of indomethacin. Arch Dis Child 1980;55:271-6.

5 Yeung CY. Bilirubin metabolism in Chinese newborn infants. Proceedings of the Centennial Conference. Hong Kong: University of Hong Kong, 1987:261-8.

6 Jacobsen J Wennberg RP. Determination of unbound bilirubin in the serum of newborns. Clin Chem 1974;20:783-9.

7 Friedman CA, Parks BR, Rawson JE, Serwer GA, Anderson $P$. Indomethacin and the preterm infant with a patent ductus arteriosus: relationship between plasma concentration and ductus closure. Dev Pharmacol Ther 1982;4:37-46.

8 Leonhardt A, Isken V, Kuhl PG, Seybeth HW. Prolonged indomethacin treatment in preterm infants with symptomatic patent ductus arteriosus: efficacy, drug level monitoring, and patient selection. Eur $\mathcal{J}$ Pediatr 1987;146: $140-4$.

9 Ramsay JM, Murphy DJ, Vick GW. Response of the patent ductus arteriosus to indomethacin treatment. $\mathrm{Am} \mathcal{J} \mathrm{Dis}$ Child 1987;141:294-7.

10 Yeung CY, Lee FT, Wong HN. Effect of a common Chinese herb on bilirubin protein binding. Biol Neonate (in press).

11 Nestrud RM, Hill DE, Arrington RW, et al. Indomethacin treatment in patent ductus arteriosus. A double-blind study
utilizing indomethacin plasma levels. Dev Pharmacol Ther utilizing indometh

12 Vert P, Bianchetti G, Marchal F, Monin P, Morselli PL. Effectiveness and pharmacokinetics of indomethacin in premature newborns with patent ductus arteriosus. Eur $\mathcal{F}$ Clin Pharmacol 1980;18:83-8

13 Mason RW, McQueen EG. Protein binding of indomethacin: binding of indomethacin to human plasma albumin and its displacement from binding by ibuprofen, phenylbutaz and salicylate in vitro. Pharmacology 1974;12:12-9.

14 Zini R, D'Athis P, Barre J. Tillement JP. Binding of indomethacin to human serum albumin. Its nondisplacement by various agents, influence of free fatty acids and the unexpected effect of indomethacin on warfarin binding. Biochem Pharmacol 1979;28:2661-5.

15 Shankaran S, Pantoja A, Poland RL. Indomethacin and bilirubin-albumin binding. Dev Pharmacol Ther 1982;4: $124-31$.

16 Leonhardt A, Isken V, Kuhl PG, Seybath HW. Prolonged indomethacin treatment in preterm infants with symotomatic patent ductus arteriosus: efficacy, drug level n toring, and patient selection. Eur $\mathcal{f}$ Pediatr 1987 toring, 